\title{
Tingkat Kecemasan Terhadap Kematian Pada ODHA
}

\author{
Gina Nur Ahdiany ${ }^{1}$, Efri Widianti ${ }^{2}$, Nita Fitria ${ }^{3}$ \\ 1,2,3 Fakultas Keperawatan Universitas Padjadjaran \\ Email: ahdianygina93@gmail.com
}

\begin{abstract}
One of the psychological impact suffered by PLWHA after HIV-AIDS was death anxiety. Excessive death anxiety would cause emotional function disorder such as neurotisma, depression, and psychosomatic disorders. The purpose of research was to describe the level of death anxiety in PLWHA in cilincing Puskesmas North Jakarta. The research was quantitative descriptive. The population was PLWHA in Puskesmas Cilincing. The samples were 30 respondents with consecutive sampling technique. The instruments used were Templer Death Anxiety Scale had done the validity test with the results of a range of values from 0.30 to 0.74 and test the reliability of 0.734 . Univariat data were analyzed by frequency distribution. The results of this analysis, it is known that more than half of respondents (56.7\%) had high death anxiety, and almost half of respondents $(43.3 \%)$ had low. It could be concluded that the newly diagnosed PLWHA over the past year to experience anxiety about the high mortality.
\end{abstract}

Keywords: anxiety, death Anxiety, PLWHA

\section{ABSTRAK}

Salah satu dampak psikologis yang dialami ODHA setelah mengidap HIV-AIDS yaitu kecemasan terhadap kematian. Kecemasan terhadap kematian yang berlebih akan menimbulkan gangguan fungsi emosional seperti neurotisma, depresi, dan gangguan psikosomatis. Tujuan penelitian ini adalah mendeskripsikan tingkat kecemasan terhadap kematian pada ODHA di Puskesmas Kecamatan Cilincing Jakarta Utara. Rancangan penelitian ini adalah deskriptif kuantitatif. Populasi penelitian ini adalah ODHA di Puskesmas Kecamatan Cilincing. Sampel pada penelitian ini sebanyak 30 responden dengan teknik pengambilan sampel consecutive sampling. Instrumen yang digunakan yaitu Templer Death Anxiety Scale yang sudah dilakukan uji validitas dengan hasil rentang nilai $0,30-0,74$ dan uji reliabilitas sebesar 0,734 . Analisis data univariat dilakukan dengan menggunakan distribusi frekuensi. Hasil dari penelitian ini yaitu diketahui bahwa lebih dari setengah responden $(56,7 \%)$ mengalami kecemasan terhadap kematian yang tinggi, dan hampir setengah responden $(43,3 \%)$ lainnya mengalami kecemasan terhadap kematian yang rendah. Dapat disimpulkan bahwa ODHA yang baru di diagnosa dalam satu tahun terakhir mengalami kecemasan terhadap kematian tinggi.

Kata kunci: Kecemasan, Kematian, ODHA 


\section{PENDAHULUAN}

HIV merupakan virus yang dapat menyerang siapa saja tanpa memandang jenis kelamin, status, ras, maupun tingkat sosial (Wahyu, Taufik \& llyas, 2012). Penyakit HIVIAIDS merupakan penyakit kronis paling berbahaya sekarang. Tidak bisa dipungkiri masalah HIVIAIDS ini tidak saja menjadi permasalahan kesehatan, tetapi juga menjadi permasalahan dan konsekuensi pada aspek sosial, spiritual, dan psikologis (Nursalam \& Kurniawati, 2007). Permasalahan pada aspek psikososial dan spiritual pada ODHA akan menimbulkan permasalahan yang kompleks yang dapat mempengaruhi perjalanan penyakit dan kondisi fisik ODHA (Armiyanti, Rahayu \& Aisah, 2015). Dampak HIVIAIDS pada aspek sosial dan spiritual seperti stigma, diskriminasi, dan kehilangan iman pada ODHA akan menambah beban pada aspek psikologis ODHA itu sendiri (Diatmi \& Fridari, 2014). Maka dari itu, penanganan pada aspek psikologis dianggap penting untuk menangani dampak-dampak yang terjadi karena penyakit HIVIAIDS ini.

Gangguan psikologis yang dialami ODHA tersebut dikelompokkan menjadi empat kelompok oleh Djoerban (1999, dalam Irawati, Subandi, \& Kumolohadi, 2011) menjadi empat jenis gangguan, yaitu gangguan afektif, gangguan kecemasan menyeluruh, keinginan untuk bunuh diri, dan gangguan otak organik (delirium atau demensia primer) yang disebabkan adanya infeksi oportunistik. Hal utama yang dirasakan pada saat ODHA pertama di diagnosa yaitu kecemasan terhadap kematian, walaupun tidak mengesampingkan kecemasan lainnya (Irawati, Subandi \& Kumolohadi, 2011). Kecemasan terjadi saat individu merasa tidak nyaman padahal ia tidak mengetahui objek penyebab terjadinya ketidaknyamanan tersebut (Comer,1992 dalam Videbeck, 2008).

Banyak faktor yang membuat seseorang merasakan kecemasan terhadap kematian diantaranya yaitu manusia tidak mengetahui apa yang dihadapinya nanti setelah kematian, masyarakat yang menganggap bahwa amalannya di dunia tidak menjamin kebahagiaan di akhirat nanti, gambaran kepedihan pengalaman mati dan sesudah mati, khawatir pada keluarga yang akan ditinggalkannya kelak, kurangnya pemahaman makna hidup dan mati, serta sebagainya (Lehto \& Stein, 2009).

Sependapat dengan Henderson (2009) disebutkan bahwa usia, lingkungan, keyakinan agama, dukungan sosial, dan integritas ego menjadi faktorfaktor yang mempengaruhi kecemasan terhadap kematian. Pendapat lain menambahkan bahwa jenis kelamin (Schumaker, Barraclough \& Vagg, 1988), status pernikahan, kondisi fisik, dan budaya (Lehto \& Stein, 2009) dapat menjadi faktor yang mempengaruhi kecemasan terhadap kematian.

Terdapat perbedaan antara kecemasan secara umum dengan kecemasan terhadap kematian, yaitu objek dari rasa ketidaknyamanan tersebut dan dampak yang ditimbulkannya. Kecemasan terhadap kematian adalah kondisi individu yang tidak menyenangkan meliputi gelisah, sulit tidur, bingung, was-was, dan tidak nyaman akibat objek yang tidak jelas atau bahkan belum terjadi berupa peristiwa saat terlepas jiwa dari raga. Satiadarma \& Zamarlita (2008) menyatakan bahwa kecemasan terhadap kematian muncul pada penderita penyakit kronis seiring dengan semakin 
melemahnya kondisi fisik, sosial, dan psikologis penderita. Kecemasan terhadap kematian yang dirasakan ODHA membuat ODHA menjadi sangat sensitif seperti gemetar, panas dingin, bahkan sampai kehilangan kesadaran, jika mendengar atau melihat berita tentang bencana, berita berduka dari kerabat ataupun hal-hal yang mendekati kematian.

Dampak lain yang membahayakan akibat kecemasan ialah pada gejala gangguan mental seperti kurang konsentrasi, depresi, perasaan bersalah, menutup diri, pikiran tidak teratur, kehilangan kemampuan persepsi, phobia, ilusi, dan halusinasi (Lutfa \& Maliya, 2008). Kecemasan terhadap kematian yang berlebihan akan menimbulkan gangguan fungsi-fungsi emosional normal manusia, seperti neurotisma, depresi, dan gangguan psikosomatis (Feifel \& Nagy,1981 pada Irawati, Subandi, \& Kumolohadi, 2011). Penelitian tentang kecemasan terhadap kematian dianggap penting untuk mencegah dampak negatif yang muncul dari kecemasan tersebut yang seharusnya tidak perlu terjadi.

Provinsi DKI Jakarta menempati peringkat pertama jumlah penderita HIV terbanyak di Indonesia dengan jumlah kasus 32.782 sampai September 2014 (Ditjen PP \& PL, Kemenkes RI, 2014). Jakarta Utara merupakan salah satu daerah epidemi penyebaran virus HIVIAIDS. Puskesmas Kecamatan Cilincing merupakan salah satu puskesmas dengan kasus HIVIAIDS yang tinggi di Jakarta Utara (Komisi Penanggulangan AIDS Indonesia, 2015). Terhitung dari Januari 2016 sampai minggu pertama April 2016 sudah terdapat 19 kasus baru HIVIAIDS. Jumlah ODHA baru sejak Januari 2015 menjadi 76 orang. $\begin{array}{ccc} & \text { Berdasarkan studi pendahuluan } \\ \text { yang dilakukan di Puskesmas }\end{array}$ Kecamatan Cilincing kepada 7 ODHA, diperoleh hasil bahwa ketujuh ODHA mengalami gejala-gejala kecemasan terhadap kematian seperti merasa tidak nyaman, gelisah, sulit tidur, bahkan selalu terlintas kematian saat ingin tidur. Tidak hanya itu, para responden juga mengeluhkan bahwa mereka mengkhawatirkan kondisi keluarga yang akan ditinggalkannya nanti ketika kematian mereka datang dan mudah merasa gelisah saat mendengar pembicaraan tentang bencana atau kematian. Dua responden dari 7 ODHA yang di wawancara juga mengatakan bahwa dirinya merasa hancur setelah di diagnosa HIVIAIDS sehingga mengganggu aktivitas sosial mereka karena mengucilkan diri dari lingkungan.

Perawatan paliatif menurut HIVIAIDS Palliative Care Guideance US Dept Of State (2006, dalam Nugroho, 2008) yaitu tindakan pelayanan perawatan untuk mencegah, memperbaiki, mengurangi gejala-gejala yang timbul dari HIVIAIDS, namun tidak untuk menyembuhkan, dan bertujuan untuk mencapai kualitas hidup yang optimal pada ODHA dan keluarganya dengan meminimalisir kesakitan dengan perawatan klinis, psikolgis, spiritual, dan sosial sepanjang perjalanan penyakit HIVIAIDS.

Perawat sebagai profesional kesehatan yang terlibat langsung dalam perkembangan kesehatan klien khususnya klien dengan HIVIAIDS memiliki peran penting sebagai care provider, advocator, dan health educator dalam membantu klien menjalani pengobatan. Perawat merupakan faktor yang berperan penting dalam pengelolaan kecemasan khusunya dalam memfasilitasi dan mengarahkan 
koping pasien yang konstruktif agar pasien dapat beradaptasi dengan sakitnya (Nursalam \& Kurniawati, 2007).

Berdasarkan fenomena yang ditemukan pada studi pendahuluan, maka peneliti tertarik untuk melakukan penelitian mengenai gambaran tingkat kecemasan kematian pada Orang dengan HIVIAIDS (ODHA) di Puskesmas Kecamatan Cilincing Jakarta Utara dengan menggunakan pendekatan teori Templer Death Anxiety Scale.

\section{METODE PENELITIAN}

Rancangan penelitian ini adalah deskriptif kuantitatif. Penelitian ini bertujuan untuk mendeskripsikan tingkat kecemasan terhadap kematian pada ODHA di Puskesmas Kecamatan Cilincing Jakarta Utara. Populasi penelitian ini adalah ODHA di Puskesmas Kecamatan Cilincing Jakarta Utara yang berjumlah 62 ODHA. Sampel pada penelitian ini sebanyak 30 responden dengan teknik pengambilan sampel yang digunakan yaitu consecutive sampling dengan kriteria inklusi: ODHA yang baru di diagnosa dalam rentang waktu Januari 2015januari 2016, datang ke Puskesmas saat waktu pengumpulan data yaitu 13 Mei 2016, dan kooperatif. Adapun kriteria ekslusi yaitu ODHA yang di diagnosa sebelum januari 2015 atau lebih dari januai 2016, sedang sakit, dan menolak menjadi responden.
Instrumen yang digunakan yaitu Templer Death Anxiety Scale berupa 15 pernyataan mengenai kecemasan terhadap kematian yang sudah dilakukan uji validitas dengan hasil rentang nilai 0,30-0,74 dan uji reliabilitas sebesar 0,734 . Analisis data analisa data dilakukan secara univariat yang bertujuan untuk mengetahui distribusi frekuensi dari berbagai tingkat kecemasan pada responden penelitian.

\section{HASIL}

Instrumen yang digunakan pada penelitian ini yaitu Templer Death Anxiety Scale yang terdiri dari 15 pernyataan yang berisi mengenai tandatanda kecemasan terhadap kematian, seperti pada tabel 1. Berdasarkan distribusi frekuensi pada tabel 1 , diketahui bahwa lebih dari setengah responden mengalami ketakutan saat memikirkan sakaratul maut yang menyakitkan, dan merasa ngeri ketika mendengar orang berbicara tentang bencana yang mungkin dapat menyebabkan terjadinya kematian.

Gambaran tingkat kecemasan terhadap kematian pada ODHA di Puskesmas Kecamatan Cilincing Jakarta Utara dapat diketahui pada tabel 1 dibawah ini: 
Tabel 1. Distribusi Frekuensi Instrumen

\begin{tabular}{clcc}
\hline No & \multicolumn{1}{c}{ Pernyataan } & Total Skor & Mean \\
\hline 1. & Saya sangat takut terhadap kematian & 19 & 0,63 \\
2. & Pikiran tentang kematian jarang menganggu pikiran saya & 17 & 0,57 \\
3. & Pembicaraan tentang kematian tidak membuat saya gugup & 10 & 0,33 \\
4. & Saya takut ketika berfikir tentang tindakan operasi yang harus saya jalani & 19 & 0,63 \\
5. & Saya sama sekali tidak takut terhadap kematian & 11 & 0,37 \\
6. & Saya tidak teralu takut dengan penyait AIDS yang saya alami & 11 & 0,37 \\
7. & Pikiran tentang kematian tidak pernah mengganggu saya & 15 & 0,50 \\
8. & Saya sering merasa tertekan (stres) karena waktu berlalu begitu cepat & 13 & 0,43 \\
9. & Saya takut mengalami sakaratul maut yang menyakitkan & 20 & 0,67 \\
10. & Berfikir tentang kehidupan setelah kematia sangat mengganggu & 13 & 0,43 \\
11. & Saya benar-benar takut terkena serangan jantung & 19 & 0,63 \\
12. & Saya sering berfikir tentang betapa pendeknya hidup ini & 16 & 0,53 \\
13. & Saya merasa ngeri ketika saya mendengar orang berbicara tentang bencana & 20 & 0,67 \\
14. & Melihat mayat mengerikan bagi saya & 15 & 0,50 \\
15. & Saya merasa tidak ada yang perlu saya takutkan tentang masa depan & 7 & 0,23 \\
\hline
\end{tabular}

\section{Tabel 2. Distribusi frekuensi tingkat kecemasan terhadap kematian pada ODHA di Puskesmas Kecamatan Cilincing Jakarta Utara $(n=30)$.}

\begin{tabular}{ccc}
\hline Kategori & $\mathrm{F}$ & $\%$ \\
\hline Rendah & 13 & 43,33 \\
Tinggi & 17 & 56,67 \\
\hline
\end{tabular}

Berdasarkan tabel 2, tingkat kecemasan terhadap kematian pada 30 ODHA di Puskesmas Kecamatan Cilincing Jakarta Utara diketahui bahwa lebih dari setengah responden yaitu $\begin{array}{llll}\text { sebanyak } 17 \text { ODHA } & (56,67 \%)\end{array}$ mengalami kecemasan terhadap kematian tinggi, sedangkan 13 ODHA $(43,33 \%)$ lainnya mengalami kecemasan terhadap kematian rendah.

Setelah dilakukan analisis lebih lanjut dengan melakukan tabulasi silang antara tingkat kecemasan terhadap kematian dengan sumber kecemasan yang dirasakan didapatkan hasil seperti pada tabel 4 berikut ini:

Kecemasan terhadap kematian timbulkan dari beberapa faktor, salah satunya yaitu proses kematian, kehidupan setelah kematian, dan
Tabel 3. Tabulasi silang tingkat kecemasan terhadap kematian dengan sumber kecemasan yang dirasakan ODHA $(n=30)$.

\begin{tabular}{|c|c|c|c|c|c|c|}
\hline & \multicolumn{4}{|c|}{$\begin{array}{c}\text { Kategori Kecemasan } \\
\text { terhadap Kematian }\end{array}$} & \multicolumn{2}{|c|}{ Total } \\
\hline & \multicolumn{2}{|c|}{ Rendah } & \multicolumn{2}{|c|}{ Tinggi } & & \\
\hline & $f$ & $\%$ & $f$ & $\%$ & $f$ & $\%$ \\
\hline Proses kematian & 9 & 69,24 & 6 & 35,30 & 15 & 50,00 \\
\hline $\begin{array}{l}\text { Kehidupan } \\
\text { setelah kematian }\end{array}$ & 2 & 15,38 & 0 & 0,00 & 2 & 6,67 \\
\hline $\begin{array}{l}\text { Keluarga yang } \\
\text { ditinggalkan }\end{array}$ & 2 & 15,38 & 11 & 64,70 & 13 & 43,33 \\
\hline Total & 13 & 100 & 17 & 100 & 30 & 100 \\
\hline
\end{tabular}

keluarga yang ditinggalkan. Berdasarkan hasil pengumpulan data yang sudah dilakukan diketahui bahwa lebih dari setengah responden $(64,70 \%)$ yang mengalami kecemasan terhadap kematian tinggi mencemaskan keluarga yang ditinggalkannya kelak, dan lebih dari setengah responden yang mengalami kecemasan terhadap kematian rendah mencemaskan proses kematian dibandingkan dengan kehidupan setelah kematian ataupun keluarga yang ditinggalkan. 


\section{PEMBAHASAN}

Berdasarkan hasil penelitian pada tabel 3 dapat diketahui bahwa tingkat kecemasan yang dirasakan oleh 30 ODHA di Puskesmas Kecamatan Cilincing Jakarta Utara menunjukkan bahwa lebih dari setengah responden yaitu sebanyak 17 ODHA (56,67\%) mengalami kecemasan terhadap kematian tinggi, sedangkan 13 ODHA lainnya (43,33\%) mengalami kecemasan terhadap kematian rendah.

dapat diketahui bahwa tingkat kecemasan terhadap kematian yang dialami ODHA di Puskesmas Kecamatan Cilincing Jakarta Utara adalah lebih dari setengah responden mengalami kecemasan terhadap kematian tinggi. Kecemasan kematian tinggi berdasarkan Templer Death Anxiety Scale (1970) yaitu jika total skor responden dalam rentang 7-15. Kecemasan terhadap kematian adalah kondisi seseorang yang menunjukkan rasa ketidaknyamanan yang terjadi terus menerus secara konstan, dan individu tersebut sibuk memikirkan proses sakaratul maut, kehilangan, ataupun yang akan terjadi setelah kematian nantinya (Langs, 1997 dalam Yuliana, 2015).

ODHA sebagai responden pada penelitian ini, menyadari bahwa rentang terhadap penyakit yang akan menggangu kesehatan fisik mereka karena sistem imunitas yang menurun dan jika koping individu tidak baik maka akan mengganggu kesehatan psikologi. Gangguan psikologi yang dirasakan pada ODHA jika terjadi terus menerus akan berpengaruh pula pada kesehatan fisik ODHA, karena membuat ODHA semakin rentan dengan infeksi sehingga kemungkinan terjadinya infeksi oportunistik semakin tinggi dan resiko mengalami kematian lebih tinggi. Tidak hanya menyebabkan menurunnya kondisi fisik, gangguan psikologis pada ODHA terutama kecemasan terhadap kematian yang berlebih akan berdampak pada fungsi emosional normal individu seperti depresi. Sejalan dengan pendapat yang dikemukakan oleh Christ (1961); Rhudick \& Dibner (1961) yang menyatakan bahwa indidvidu yang mengalami kecemasan terhadap kematian yang tinggi dipengaruhi oleh masalah pada kesehatan fisik dan emosional yang buruk (Yuliana, 2015). Pendapat lain juga mengemukakan bahwa satu dari tiga tantangan utama yang dihadapi oleh individu yang menderita HIV-AIDS adalah mengembangkan koping individu efektif untuk mempertahankan kondisi fisik dan psikis ODHA (Sari \& Haryati, 2015). Kecemasan terhadap kematian dapat disebabkan oleh beberapa hal salah satunya yaitu penyakit yang sedang dialami (Chan \& Yap, 2009). Sehingga dapat disimpulkan bahwa kondisi fisik menjadi salah satu faktor yang berpengaruh menimbulkan kecemasan terhadap kematian.

Kecemasan biasanya timbul saat individu baru di diagnosa suatu penyakit akut ataupun kronis (Kirunda 2007). Sesuai dengan hasil pengumpulan data yang sudah dilakukan, diketahui bahwa 17 ODHA $(56,7 \%)$ dari 30 responden yang baru didiagnosa dalam 1 tahun terakhir merasakan kecemasan terhadap kematian yang tinggi. Sembilan $(69,2 \%)$ dari tiga belas responden yang di diagnosa pada bulan September 2015 sampai Januari 2016 mengalami kecemasan terhadap kematian yang tinggi. ODHA yang baru di diagnosa akan mengalami proses berduka seperti yang dikemukakan oleh Kubler Ross yaitu tahap denial, tahap kemarahan, tahap negosiasi, tahap depresi, dan 
tahap penerimaan. Tidak semua individu dapat melewati kelima tahapan berduka dengan baik, dan individu yang mengalami kegagalan adapatasi akan menyebabkan reaksi-reaksi lain (Dalami, et al, 2009). Banyak hal yang dipikirkan oleh ODHA saat baru didagnosa seperti kondisi kesehatannya mendatang, sisa usia yang ada, respon dari keluarga serta lingkungan mengenai penyakitnya, pekerjaannya, dan lain sebagainya, sehingga emosi yang dirasakan menjadi tidak stabil, dan salah satu akibat dari gangguan tersebut yaitu timbulnya kecemasan.

Pada hasil penelitian ini diketahui bahwa hampir setengah responden yaitu 13 ODHA (43,3\%) mengalami kecemasan terhadap kematian yang rendah. Tingkat kecemasan yang rendah ini dapat disebabkan oleh koping individu yang baik. Individu yang sudah menerima keadaannya cenderung akan mempersiapakan kematiannya, seperti memanfaatkan waktu yang tersisa dengan melakukan hobi, berkumpul dengan keluarga, meraih cita-cita yang belum tercapai, dan lain sebagainya. Mereka mengganggap lebih baik memanfaatkan waktu yang tersisa sebaik mungkin dibandingkan dengan memikirkan hal-hal yang mengganggu kenyamanan mereka seperti kematian. Sesuai dengan pendapat Ollich, et al dalam Winarto (2007) bahwa seseorang yang memiliki pertahanan diri yang baik atau sering disebut mekanisme koping efektif akan menurunkan kemungkinan terjadinya kecemasan dan depresi. Sependapat dengan Dalami, et.al (2009) bahwa individu yang berhasil melewati proses berduka dapat menerima keadaanya dengan lapang dada, bahkan siap menghadapi apapun yang terjadi dengan perasaan damai, walaupun sebelumnya ia melewati fase penerimaan dengan berat hati.

Terdapat lima faktor komponen yang terbagi-bagi di dalam instrumen Templer Death Anxiety Scale (Tavakoli, Ali, \& Behrooz, 2011). Faktor pertama yaitu kecemasan terhadap kematian mutlak yang terdiri dari penyataan nomor 1, 5, dan 7. Diketahui memiliki jumlah nilai $45(50 \%)$, yang berarti setengah dari responden merasakan kecemasan terhadap kematian melalui pemikiranpemikiran dirinya sendiri. Kecemasan kematian yang dirasakan para ODHA menimbulkan pikiran-pikiran tentang kematian yang mengganggu kehidupannya, bahkan pada beberapa individu merasakan sulit tidur, gelisah, selalu terlintas tentang kematian, sampai mengucilkan diri dari lingkungannya karena tahu bahwa dirinya sebentar lagi akan meninggal. Seseorang yang mengalami kecemasan terhadap kematian akan merasakan ketidaknyamanan seperti kegelisahan, ketegangan, dan pikiran penuh dengan bayangan proses sakaratul maut, kehilangan, dan setelah kematian (Abdel-Khalek, 2005). Dapat disimpulkan bahwa individu yang mengalami kecemasan kematian akan menimbulkan ketidaknyaman pada dirinya yang dapat mengganggu aktivitas kesehariannya.

Dari beberapa sumber penyebab kecemasan terhadap kematian yang dikaji saat penelitian, dari 30 responden sebanyak 15 ODHA (50\%) mengatakan bahwa ia mencemaskan proses kematian. Tiga belas ODHA lainnya $(43,3 \%)$ menyebutkan bahwa keluarga yang ditinggalkan menjadi penyebab kecemasan terhadap kematian mereka. Dua responden lainnya $(6,67 \%)$ mengatakan mencemaskan kehidupan setelah kematian. Kematian merupakan suatu proses yang hakiki yang akan 
dilewati oleh setiap orang, tidak mengenal usia, jenis kelamin, kondisi fisik atau apapun latar belakangnya, dan kematian itu sendiri akan datang pada waktu yang tidak kita ketahui. Sampai sekarang belum ada penjelasan secara ilmiah yang dapat menjelaskan kepastian datangnya kematian pada seseorang (Zubair, 2008 dalam Wijayanti \& Lailatushifah 2012). Hal tersebut sependapat dengan Shibab (2007) mengatakan bahwa kecemasan terhadap kematian dirasakan oleh seseorang karena belum ada pengalaman tentang kematian pada diri individu dan tidak adanya kepastian mengenai datangnya hari kematian pada individu tersebut (Wijayanti \& Lailatushifah, 2012). Individu yang mengalami kecemasan tidak dapat menjelaskan dengan pasti objek dari rasa ketidaknyamanan yang dirasakan, termasuk pada individu yang mengalami kecemasan terhadap kematian. Individu tersebut hanya dapat menunjukkan tanda gejala mengalami kecemasan terhadap kematian seperti jantung berdebar-debar, keringat dingin, gemetar, merinding, bahkan sampai pingsan saat mendengar atau membayangkan hal-hal yang berkaitan dengan kematian misalnya bencana atau kabar kematian dari kerabat.

Faktor kedua yaitu ketakutan dari kegelisahan dan nyeri, yang terdiri dari pernyataan nomor 4, 6, 9 dan 11 . Pada penelitian yang sudah dilakukan faktor kedua ini memiliki jumlah skor 69 $(57,5 \%)$, sehingga diketahui bahwa lebih dari setengah responden merasakan ketakutan dari kegelisahan dan rasa nyeri. Penyakit HIV-AIDS yang ODHA derita akan menyebabkan dirinya rentang terhadap penyakit terutama pada infeksi oportunistik dan waktu kesembuhan pada ODHA menjadi lebih lama, bahkan tidak sedikit ODHA yang menjadi mengalami komplikasi penyakit, keadaan ini akan memungkinkan ODHA menderita sakit sampai datang waktu kematiannya. Ini menjadi beban pemikiran ODHA, yang bila tidak ditangani dapat menyebabkan tekanan psikologis pada ODHA yang bisa memperburuk kondisi kesehatannya. Penelitian ini sesuai dengan asumsi dari Abdel-Khalek (2005) yang mengatakan bahwa kecemasan terhadap kematian berhubungan dengan kesakitan atau penderitaan individu yang mungkin disertai dengan datangnya kematian dan juga cara kematian dari individu tersebut.

Faktor ketiga yaitu kematian berhubungan dengan pemikiran terdiri dari pernyataan nomor 3, 10, dan 14 . Faktor ketiga memiliki jumlah skor 38, maka kurang dari setengah responden $(42,3 \%)$ merasakan kecemasan kematian karena pemikiran mereka tentang kematian. Lingkungan sebagai faktor eksternal sangat berpengaruh pada mekanisme koping manusia. Jika suatu lingkungan tersebut terdapat banyak kasus kematian ataupun penyebab-penyebab kematian akan meningkatkan kecemasan terhadap kematian. Ditambah lagi dengan pengetahuan individu mengenai kematian yang kurang akan berpengaruh pada kecemasan terhadap kematian yang dirasakan dan tak jarang justru akan meningkatkan kejadian kecemasan terhadap kematian. Saat individu tidak mengetahui makna dari hidup dan mati, individu tersebut akan menimbulkan kecemasan terhadap kematian. Sependapat dengan yang dikemukakan oleh Lehto dan Stein (2009) bahwa manusia memiliki emosional negatif, sehingga hanya dengan memikirkan atau membayangkan kematian atau melihat mayat saja dapat menimbulkan 
kecemasan terhadap kematian. Dikatakan juga dalam teori Templer (1970) yang menyebutkan bahwa salah satu faktor kecemasan terhadap kematian yaitu pengalaman tentang kematian. Faktor tersebut didasari oleh prinsip belajar dan pengaruh lingkungan.

Faktor keempat yaitu masa lalu dan kehidupan yang pendek terdiri dari pernyataan nomor 2, 8, dan 12 . Dari 30 responden, lebih dari setengah responden $\quad(51,1 \%) \quad$ merasakan kehidupan yang pendek dan bermasalah dengan masa lalu. Berfikir tentang waktu kehidupan merupakan gejala yang ditimbulkan dari kecemasan. Waktu kehidupan hanya sebagai objek yang tidak pasti akibat dari kecemasannya terhadap kematian. Individu tersebut mencemaskan kedatangan kematian pada dirinya sehingga ia beranggapan bahwa waktu yang ia jalani sangat pendek. Individu juga beranggapan bahwa masih banyak hal yang belum dilakukan olehya seama masa hidupnya ini, dan tak jarang keadaan ini membuat individu rentang merasakan gelisah.

Faktor terakhir yaitu takut masa depan yang terdiri dari pernyataan 13 , dan 15. Hampir dari setengah responden $(45 \%)$ merasa takut terhadap masa depan. Hampir setiap orang yang mendengar pembicaraan tentang bencana akan merasa takut, mereka membayangkan jika bencana tersebut terjadi kepada dirinya ataupun keluarganya. Begitu pun yang terjadi pada ODHA, saat pengumpulan data yang dilakukan 20 responden mengatakan bahwa dirinya merasa ngeri jika mendengarkan ada orang yang membicarakan tentang bencana, mereka beranggapan bahwa bencana yang terjadi sangat dekat dengan kematian, dan mereka merasa cemas jika mereka yang mengalaminya. Kecemasan terhadap kematian hanya dialami pada individu yang tidak mempunyai pengetahuan mengenai hakikat kematian, atau tujuan setelah datangnya kematian. mengetahui hakikat kematian, atau tidak mengetahui tujuan setelah mati (Maskawaih dalam Zubair, 2008). Individu kurang memaknai makna hidup mati menduga apa yang dikerjakan di dunia tidak akan menjamin kebahagiaan di akhirat nanti.

\section{KESIMPULAN}

ODHA di Puskesmas

Kecamatan Cilincing Jakarta Utara lebih dari setengah mengalami kecemasan terhadap kematian yang tinggi sedangkan responden lainnya mengalami kecemasan terhadap kematian rendah. Kecemasan terhadap kematian tinggi dialami oleh seseorang yang merasakan ketidaknyamanan yang terjadi secara terus menerus dan pikirannya dipenuhi dengan proses sakaratul maut, kehilangan, atau yang akan terjadi setelah kematian. Puskesmas Kecamatan Cilincing Jakarta Utara dapat melakukan program promotif dan preventif untuk menurunkan tingkat kecemasan terhadap kematian kepada ODHA di Poli Infeksi Menular Seksual dengan meningkatkan dukungan sosial dan spiritual.

\section{DAFTAR PUSTAKA}

Abdel-Khalek, A. M., \& Tomas-Sabado, J. (2005). Anxiety and death anxiety in Egyptian and Spanish nursing students. Death Studies, 29(2), 157-169.

Armiyati, Y., Rahayu, D. A., \& Aisah, S. (2015). Manajemen masalah psikososiospiritual pasien hiv/aids di kota semarang. In Prosiding seminar nasional \& international. 548-556. 
Chan, L. C., \& Yap, C. C. (2009). Age, gender, and religiosity as related to death anxiety. Sunway Academic Journal, 6, 1-16.

Diatmi, K., \& Fridari, D. (2014). Hubungan Antara Dukungan Sosial dengan Kualitas Hidup pada Orang Dengan HIV dan AIDS (ODHA) Di Yayasan Spirit Paramacitta. Jurnal Psikologi Udayana, 1(2), 353-362.

Miller, A. K., Lee, B. L., \& Henderson, C. E. (2012). Death anxiety in persons with HIVIAIDS: a systematic review and metaanalysis. Death studies, 36(7), 640-663.

Irawati, D., Subandi, M. A., \& Kumolohadi, R. (2011). Terapi Kognitif Perilaku Religius untuk Menurunkan Kecemasan terhadap Kematian pada Penderita HIVIAIDS. Jurnal Intervensi Psikologi, 3(2), 169186.

Kemenkes RI. (2014). Situasi dan analisis HIV AIDS. Jakarta: Pusat data dan informasi Kemenkes RI.

Lehto, R. H., \& Stein, K. F. (2009). Death Anxiety: An Analysis of an Evolving Concept. Research and Theory for Nursing Practice: An International Journal, 10.189/1541-6577.23.1.23, 2341.

Wahjudi, N. (2008). Keperawatan Gerontik dan Geriatrik. Jakarta: EGC.

Nursalam, D. K., \& Dian, N. (2007). Asuhan keperawatan pada pasien terinfeksi HIV. Jakarta: Salemba Medika.
Sari, M. D. I., \& Hayati, E. N. (2015). Regulasi emosi pada penderita HIVIAIDS. EMPATHY Jurnal Fakultas Psikologi, 3(1), 23-30.

Wijayanti, A., \& Lailatushifah, S. N. F. (2012). Kebermaknaan Hidup dan Kecemasan terhadap Kematian pada Orang dengan Diabetes Melitus. Jurnal INSIGHT, 10(1), 49-63

Tavakoli, M, A \& Behrooz, A. (2011). Investigation of validity and reliability of templer death anxiety scale. Throught \& behaviour in clinical psychology $6(21), 72-80$.

Templer, D. I. (1970). The Construction and Validation of a Death Anxiety Scale. The Journal of General Psychology, 82, 165177.

Viedebeck, S.L. (2008). Buku Ajar Keperawatan Jiwa. Jakarta: EGC

Wahyu, S., Taufik, T., \& Ilyas, A. (2012). Konsep Diri dan Masalah yang Dialami Orang Terinfeksi HIVIAIDS. Konselor, 1(2), 1-12.

Yuliana. (2015). Mengatasi kecemasan terhadap kematian pada pasien sakit parah melalui konseling kelompok. Psychology Forum UMM, 978-979-796-324-8, 458463.

Ziapour, S.S., Dusti, Y.A., \& Asfajir, A.A. (2014). The Correlation Between Happines And Death Anxiety: A Case Study In Health Personel Of Zareh Hospital Of Sari. European Journal of Experimental Biology, 4(2), 172177. 